\title{
Self-rated health status and lifestyle factors: A cross-sectional study of human and natural science educators
}

\author{
Pâmela Vieira Monteiro', Gabriela Silvério das Neves', Geise Ferreira da Cruz', Monica Cattafesta², \\ Roberta Luksevicius Rica ${ }^{3}$, Almir de França Ferraz ${ }^{3}$, Aylton Figueira Junior ${ }^{3}$, Michell Vetoraci Viana ${ }^{3}$, \\ Guilherme Lemos Shimojo ${ }^{4}$, Luciane Bresciani Salaroli ${ }^{2}$
}

\begin{abstract}
:
Background: Self-rated health status is a subjective indicator that is based on the body's perception of health status, covering personal components such as, physical aspects, aspects of general well-being and satisfaction with life. Objective: To analyze the self-rated health status and factors associated with the lifestyle of higher education educators. Material and methods: This is an observational study, consisting of 85 faculty members in the area of Human and Natural Sciences of a university. For the analysis of the sample, chi-square test and Fisher's exact test were used. Results: $24.7 \%(n=21)$ self-rated their health as regular/poor. $(P=0.022)$, the Waist/Stature ratio $(p=0.014)$, the level of physical activity $(p=0.050)$, the time in administrative positions $(p=0.026)$ and stress-related symptoms $(p=0.043)$. Conclusion: The time in administrative position and the large number of symptoms related to stress, high PW, inadequate $\mathrm{W} / \mathrm{S}$ ratio and low level of physical activity were associated with negative self-rated health, recommending strategies for promotional health and prevention of stress-related diseases.
\end{abstract}

KEYWORDS: Self-rated Health; Lifestyle; Physical Activity; Work`s Health.

\section{BACKGROUND}

Self-rated health status is a subjective indicator that is based on the body's perception of health status, covering personal components such as, physical aspects, aspects of general well-being and satisfaction with life ${ }^{(1,2,3)}$. The use of this indicator is increasingly frequent in epidemiological studies, since it is easy to apply individually or to populations. Additionally, previous studies reported that self-rated health is a good tool as a predictor of morbidity among population subgroups, to compare healthy service and mortality ${ }^{(3,4)}$. Since negative self-rating induces the demand for health services ${ }^{(2)}$, the World Health Organization (WHO) recommends the use of this indicator as it makes it possible to evaluate the effectiveness of public policies, actions and health services, and can be incorporated into the health surveillance system due to its easy accessibility ${ }^{(5)}$. Although widely used in population-based studies as well as general population ${ }^{(2,6,7)}$ or groups of specific workers ${ }^{(8,9)}$. Studies on health self-rating in higher education educators is still scarce considering the importance of these professionals in the educational sphere and society. Currently, the teaching profession is considered one of the leading causes of stress and occupational diseases ${ }^{(10)}$. Given that higher education educators often face a grueling routine, the accumulation of functions, the demand for scientific production, the lack of infrastructure and university investment, and the constant demand for updates that tend to have an unfavorable impact on health and performance ${ }^{(11)}$. Taking in consideration that high stress level is associated with negative self-rating. Here, we assess self-rated health status and factors associated with the lifestyle of higher education educators in the areas of Human and Natural Sciences.

\section{MATERIAL AND METHODS}

It is an observational, transversal and descriptive investigation. The sample is non-probabilistic, for convenience, being made up of effective professors of the Human Sciences (Psychology, Letters, History, Social Sciences, Geography and Philosophy) and Natural Sciences (Biology and Oceanography) of a public university of both sexes, in a regime of exclusive dedication and in full working activity. Educators in probationary stage, pregnant, lactating, under license, who did not complete the questionnaire and did not respond to the invitation were excluded from the survey. Data collection occurred from September to December 2016 and from March to June 2017. All the educators were invited to

Corresponding author: Luciane Bresciani Salaroli. Address: Universidade Federal do Espírito Santo. Departamento de Educação em Saúde (DEIS). Av. Marechal Campos, 1468, DEIS - Maruípe, Vitória (ES), Brazil - CEP: 29040-090. E-mail: lucianebresciani@gmail.com

2 Programa de Pós-Graduação em Saúde Coletiva da Universidade Federal do Espírito Santo (UFES), Vitória (ES), Brasil

Full list of author information is available at the end of the article.

Financial support: nothing to declare

Submission date 04 November 2018; Acceptance date 14 December 2018; Publication 28 December 2018 
participate, through the coordination meetings of each course, in which they were informed about the research. Subsequently, individual schedules were arranged via telephone contact, in person or by e-mail, to conduct the interview. The study was approved by the Committee of Ethics in Research with Human Beings of the Health Sciences Center of the Federal University of Espírito Santo under the CAAE: 56159316.5.0000.5060. All the participants signed the Informed Consent Term. The independent variables used were socioeconomic and demographic data, anthropometric, hemodynamic, behavioral, work characteristics and health conditions (Figure 1).

The socioeconomic and demographic data were age, sex, marital status and economic class. The age range was categorized as "up to 40 years", "between 41 and 50 years" and "over 50 years", marital status "living marital" and "not living marital" and socioeconomic data classified according to Criteria of Economic Classification Brazil(12). The anthropometric, hemodynamic and behavioral variables were used in the study, the Body Mass Index (BMI) given by weight $(\mathrm{kg}) /$ height $\left(\mathrm{m}^{2}\right)$, the adequacy of weight (\%) given by actual weight $x 100 /$ ideal weight, the Waist Perimeter (WP), Waist/Stature (W/S), Arterial Blood Pressure (AP), alcohol, smoking and physical activity levels. BMI ranged from low weight / eutrophy (BMI $\left.<24.99 \mathrm{~kg} / \mathrm{m}^{2}\right)$ and overweight / obesity $\left(\mathrm{BMI}>25 \mathrm{~kg} / \mathrm{m}^{2}\right)^{(5)}$. Weight adequacy was obtained using the formula (actual weight $x 100$ / ideal weight) and regrouped in "adequate"
$(<110 \%)$ and "not adequate" (> 110.1\%) ${ }^{(13)}$. For analysis of the WP, an inextensible metric tape was used positioned at the mid horizontal point between the lower margin of the last costal arch and the iliac crest. Categorized as adequate and inadequate, considering inadequate $\mathrm{CP} \geq 94 \mathrm{~cm}$ for men and $\geq 80 \mathrm{~cm}$ for women ${ }^{(14)}$. The variable $S / W$ ratio was grouped into adequate and inadequate, using a cut-off point $>0.5$ for inadequate, adopted by the Brazilian Obesity guideline $2016^{(14)}$. Subjects with high BP were considered those who used antihypertensive drugs and / or who had the mean blood pressure measured during the interview, and for systolic blood pressure (SBP) greater than $140-159 \mathrm{mmHg}$ and diastolic blood pressure (DBP) 90- $99 \mathrm{mmHg}^{(15)}$. Considered who consumed alcohol regardless of frequency or quantity and smokers who used tobacco / tobacco regardless of quantity or frequency. Being the variables regrouped in "consume", "never / already consumed in the past".

The reduced version of the International Physical Activity Questionnaire (IPAQ), validated for the Brazilian population, was used to evaluate the level of physical activity ${ }^{(16)}$, being considered sufficiently active individuals, those who reported at least 150 minutes of activities with frequency $\geq 5$ days in the week $^{(17)}$, considering the sum of the sessions related to leisure and transportation, in order to avoid overestimation of the level of physical activity ${ }^{(18)}$. To characterize the works environment, we used questions such as: resides in the city

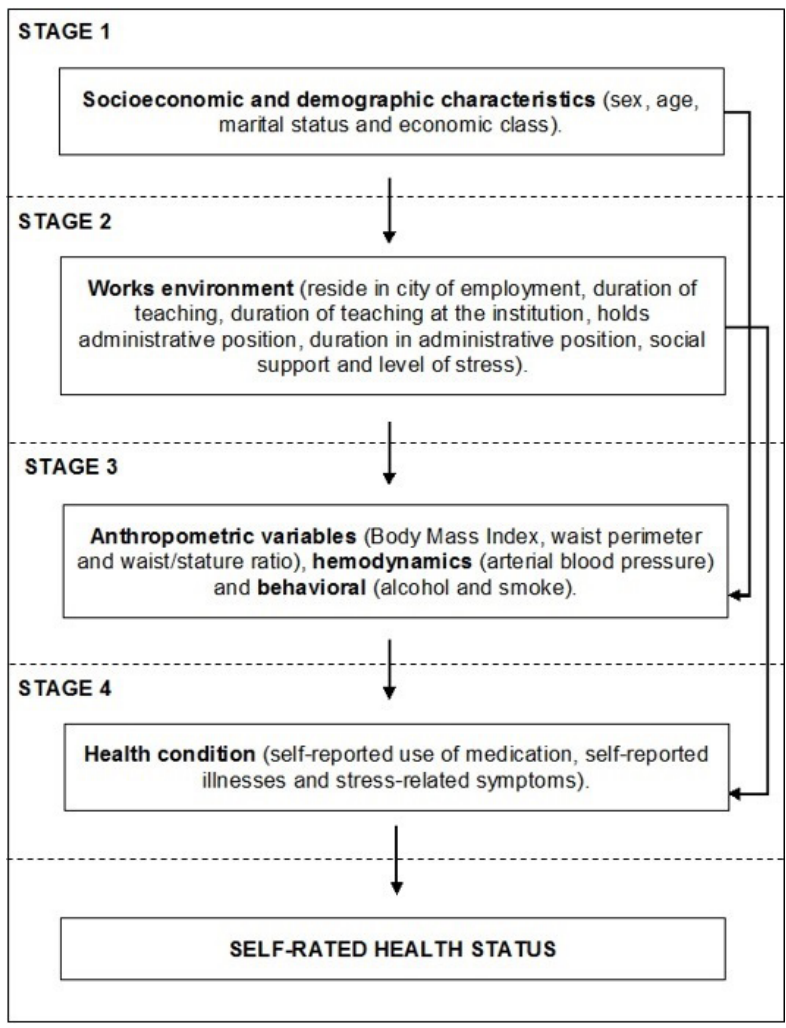

Figure 1. Theoric model. 
they work, teaching time, teaching time in the institution, holds administrative position, administrative office time, social support and stress level ${ }^{(19)}$. The variable time as a educator was categorized into "up to 20 years" and "over 20 years" and time as a educator in the institution categorized as "up to 10 years" and "over 10 years". The variable of administrative position was categorized as "yes, exercises" and "no, does not exercise" and the time in the administrative position was grouped in "up to 1 year" and "over 1 year". In order to determine the level of occupational stress, the reduced and adapted version for Brazil of the Job Stress Scale, evaluated by the demand and control model and regrouped in "not stressed" and "stressed" was used. In order to evaluate social support, it was regrouped in "low social support" and "high social support" according to the reduced and adapted version of Job Stress Scale ${ }^{(19)}$.

To characterize the health condition, the following variables were selected: self-reported use of drugs categorized as "yes" or "no", amount of self-reported drugs, self-reported illnesses and stress-related symptoms. The amount of medication was grouped "between 0 and 2 and "more than 2 diseases." Concerning stress symptoms, they were grouped into "up to 5 symptoms" and "more than 5 symptoms". The dependent variable of interest is "self-rating health status". The educator was asked: "In general, how would he classify his state of health in relation to other individuals of the same age", with the option of "very good", "good", "regular" and " bad". Later grouped in "very good / good" and "regular / bad", to make the analysis more representative. The data was analyzed in the SPSS ${ }^{\circledR}$ program, version 22 , and the chi-square test $\left(\mathrm{X}^{2}\right)$ and Fisher's exact test were used for the categorized analysis, adopting a significance level of $5 \%$.

\section{RESULTS}

Among the 217 permanent active educators, $12.90 \%(n=28)$ were excluded because they were not in work activity of their functions. Thus, 189 active educators in the function, $44.9 \%$ $(n=85)$ accepted to participate in the research meeting the inclusion criteria. Among the 44.9\% ( $n=85)$ educators, $50.6 \%$ $(n=43$ ) were males; the predominant age group was "over 50 years" representing $45.9 \%(n=39)$ of the sample; $58.8 \%$ $(n=50)$ were married and $70.6 \%(n=60)$ were classified in economy class A1/A2. Regarding the self-rated health status, $24.7 \%(n=21)$ self-rated their health as regular/poor. None of the socioeconomic and demographic variables (Table 1) were associated with self-rated health status.

In relation to the anthropometric, behavioral and lifestyle variables, the values of the $C P(p=0.022)$, the $C / E$ ratio $(p=0.014)$ and the physical activity level $(p=0.050)$. These were associated with negative (regular/poor) self-rated health status in educators considered inadequate and/or insufficient. The highest percentage was present in the individuals classified with the inadequate $\mathrm{C} / \mathrm{E}$ ratio (Table 2 ). About $68.2 \%(n=58)$ of the evaluated educators were overweight, although there was no statistical difference.

From the characteristics of the work presented in Table 3, there was identified an association with the self-rated health status, only the time in administrative positions ( $p=0.026)$, being prevalent the regular / bad self-evaluation of those who exercised administrative position up to 1 year.

When analyzing the variables related to the health condition of the educators (Table 4), there was a significant correlation between the stress-related symptoms ( $p=0.043)$ and negative self-rated health status, being higher in educators who presented five or more symptoms.

Table 1. Self-rated health status according to socioeconomic and demographic characteristics [[Q1: Q1]].

\begin{tabular}{|c|c|c|c|c|c|c|c|}
\hline \multirow{2}{*}{ Parameters } & \multicolumn{2}{|c|}{ Very good/good } & \multicolumn{2}{|c|}{ Regular/bad } & \multirow{2}{*}{ Significance } & \multicolumn{2}{|c|}{ Total } \\
\hline & $\mathbf{N}$ & $\%$ & $\mathbf{n}$ & $\%$ & & n & $\%$ \\
\hline \multicolumn{8}{|l|}{ Sex* } \\
\hline Female & 29 & 45.3 & 13 & 61.9 & \multirow{2}{*}{0.216} & 42 & 49.4 \\
\hline Male & 35 & 54.7 & 8 & 38.1 & & 43 & 50.6 \\
\hline \multicolumn{8}{|l|}{ Age } \\
\hline Up to 40 years & 16 & 25.0 & 5 & 23.8 & \multirow{3}{*}{0.579} & 21 & 24.7 \\
\hline Between 41 and 50 years & 17 & 26.6 & 8 & 38.1 & & 25 & 29.4 \\
\hline More than 50 years & 31 & 48.4 & 8 & 38.1 & & 39 & 45.9 \\
\hline \multicolumn{8}{|l|}{ Marital status* } \\
\hline Married & 38 & 59.4 & 12 & 57.1 & \multirow{2}{*}{0.999} & 50 & 58.8 \\
\hline Single & 26 & 40.6 & 9 & 42.9 & & 35 & 41.2 \\
\hline \multicolumn{8}{|l|}{ Economic class* } \\
\hline $\mathrm{A} 1 / \mathrm{A} 2$ & 44 & 68.8 & 16 & 76.2 & \multirow{2}{*}{0.591} & 60 & 70.6 \\
\hline B1/B2 & 20 & 31.3 & 5 & 23.8 & & 25 & 29.4 \\
\hline
\end{tabular}

Note: Chi-square test. ${ }^{*}$ Fischer test. $\mathrm{N}=85$ 
Table 2. Self-rated health status and lifestyle according to anthropometric and behavioral variables.

\begin{tabular}{|c|c|c|c|c|c|c|c|}
\hline & \multicolumn{2}{|c|}{ Very good/good } & \multicolumn{2}{|c|}{ Regular/bad } & \multirow{2}{*}{ Significance } & \multicolumn{2}{|c|}{ Total } \\
\hline & $\mathrm{n}$ & $\%$ & $\mathbf{N}$ & $\%$ & & 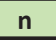 & $\%$ \\
\hline \multicolumn{8}{|l|}{ Body mass index } \\
\hline Low weight / eutrophic & 24 & 37.5 & 3 & 14.3 & \multirow{2}{*}{0.060} & 27 & 31.8 \\
\hline Overweight / Obesity & 40 & 62.5 & 18 & 85.7 & & 58 & 68.2 \\
\hline \multicolumn{8}{|l|}{ Arterial blood pressure* } \\
\hline Normal & 49 & 76.6 & 13 & 61.9 & \multirow{2}{*}{0.257} & 62 & 72.9 \\
\hline High & 15 & 23.4 & 8 & 38.1 & & 23 & 27.1 \\
\hline \multicolumn{8}{|l|}{ Adequacy of body weight* } \\
\hline Suitable & 34 & 53.1 & 7 & 33.3 & \multirow{2}{*}{0.137} & 41 & 48.2 \\
\hline Not suitable & 30 & 46.9 & 14 & 66.7 & & 44 & 51.8 \\
\hline \multicolumn{8}{|l|}{ Waist perimeter* } \\
\hline Suitable & 31 & 48.4 & 4 & 19.0 & \multirow{2}{*}{0.022} & 35 & 41.2 \\
\hline Not suitable & 33 & 51.6 & 17 & 81.0 & & 50 & 58.8 \\
\hline \multicolumn{8}{|c|}{ Waist perimeter/heigh ratio* } \\
\hline Suitable & 25 & 39.1 & 2 & 9.5 & \multirow{2}{*}{0.014} & 27 & 31.8 \\
\hline Not suitable & 39 & 60.9 & 19 & 90.5 & & 58 & 68.2 \\
\hline \multicolumn{8}{|l|}{ Alcohol } \\
\hline Consume & 52 & 81.3 & 16 & 76.2 & \multirow{2}{*}{0.754} & 68 & 80.0 \\
\hline Never/Stopped & 12 & 18.8 & 5 & 23.8 & & 17 & 20.0 \\
\hline \multicolumn{8}{|l|}{ Smoke } \\
\hline Consume & 6 & 9.4 & 5 & 23.8 & \multirow{2}{*}{0.130} & 11 & 12.9 \\
\hline Never/Stopped & 58 & 90.6 & 16 & 76.2 & & 74 & 87.1 \\
\hline \multicolumn{8}{|l|}{ Level of physical activity* } \\
\hline Active & 51 & 79.7 & 12 & 57.1 & \multirow{2}{*}{0.050} & 63 & 74.1 \\
\hline Inactive & 13 & 20.3 & 9 & 42.9 & & 22 & 25.9 \\
\hline
\end{tabular}

Note: * Fisher's exact test. $\mathrm{N}=85$

Table 3. Self-rated health status, according to characteristics of the work.

\begin{tabular}{|c|c|c|c|c|c|c|c|}
\hline \multirow{2}{*}{ Parameters } & \multicolumn{2}{|c|}{ Very good/good } & \multicolumn{2}{|c|}{ Regular/bad } & \multirow{2}{*}{ Significance } & \multicolumn{2}{|c|}{ Total } \\
\hline & $\mathbf{N}$ & $\%$ & $\mathbf{n}$ & $\%$ & & $\mathbf{N}$ & $\%$ \\
\hline \multicolumn{8}{|l|}{ Reside in city of employment } \\
\hline Yes & 44 & 68.8 & 13 & 61.9 & \multirow{2}{*}{0.599} & 57 & 67.1 \\
\hline No & 20 & 31.3 & 8 & 38.1 & & 28 & 32.9 \\
\hline \multicolumn{8}{|c|}{ Duration of teaching at the institution } \\
\hline Up to 10 years & 28 & 43.8 & 12 & 57.1 & \multirow{2}{*}{0.322} & 40 & 47.1 \\
\hline More than 11 years & 36 & 56.3 & 9 & 42.9 & & 45 & 52.9 \\
\hline \multicolumn{8}{|l|}{ Duration of teaching } \\
\hline Up to 20 years & 37 & 57.8 & 10 & 47.6 & \multirow{2}{*}{0.456} & 47 & 55.3 \\
\hline More than 20 years & 27 & 42.2 & 11 & 52.4 & & 38 & 44.7 \\
\hline \multicolumn{8}{|l|}{ Holds administrative position } \\
\hline Yes & 31 & 48.4 & 10 & 47.6 & \multirow{2}{*}{0.999} & 41 & 48.2 \\
\hline No & 33 & 51.6 & 11 & 52.4 & & 44 & 51.8 \\
\hline \multicolumn{8}{|c|}{ Duration in administrative position } \\
\hline Up to 1 year & 11 & 35.5 & 8 & 80.0 & \multirow{2}{*}{0.026} & 19 & 22.4 \\
\hline More than 1 year & 20 & 64.5 & 2 & 20.0 & & 22 & 25.9 \\
\hline \multicolumn{8}{|l|}{ Social support } \\
\hline Low social support & 30 & 46.9 & 9 & 42.9 & \multirow{2}{*}{0.805} & 39 & 45.9 \\
\hline High social support & 34 & 53.1 & 12 & 57.1 & & 46 & 54.1 \\
\hline \multicolumn{8}{|l|}{ Level of stress* } \\
\hline Low & 37 & 58.7 & 17 & 81.0 & \multirow{2}{*}{0.073} & 54 & 63.5 \\
\hline High & 26 & 41.3 & 4 & 19.0 & & 30 & 35.3 \\
\hline
\end{tabular}

Note: Fisher's exact test. $\mathrm{N}=85 .{ }^{*} \mathrm{~N}=84$. 
Table 4. Self-rated health status, according to variables of health condition.

\begin{tabular}{|c|c|c|c|c|c|c|c|}
\hline \multirow{2}{*}{ Parameters } & \multicolumn{2}{|c|}{ Very good/good } & \multicolumn{2}{|c|}{ Regular/bad } & \multirow{2}{*}{ Significance } & \multicolumn{2}{|c|}{ Total } \\
\hline & $\mathbf{N}$ & $\%$ & $\mathrm{n}$ & $\%$ & & $n$ & $\%$ \\
\hline \multicolumn{8}{|l|}{ Use of medication* } \\
\hline Yes & 35 & 54.7 & 10 & 47.6 & \multirow{2}{*}{0.621} & 45 & 52.9 \\
\hline No & 29 & 45.3 & 11 & 52.4 & & 40 & 47.1 \\
\hline \multicolumn{8}{|l|}{ Quantity of medicines*** } \\
\hline Between 0 and 2 medications & 62 & 96.9 & 20 & 95.2 & \multirow{2}{*}{0.999} & 82 & 96.5 \\
\hline More than 2 medications & 2 & 3.1 & 1 & 4.8 & & 3 & 3.5 \\
\hline \multicolumn{8}{|l|}{ Self-reported illnesses ${ }^{1, *}$} \\
\hline Up to 2 diseases & 30 & 46.9 & 5 & 23.8 & \multirow{2}{*}{0.077} & 35 & 41.2 \\
\hline More than 2 diseases & 34 & 53.1 & 16 & 76.2 & & 50 & 58.8 \\
\hline \multicolumn{8}{|l|}{ Stress-related symptoms ${ }^{2 *}$} \\
\hline Up to 5 symptoms & 36 & 56.3 & 6 & 28.6 & \multirow{2}{*}{0.043} & 42 & 49.4 \\
\hline More than 5 symptoms & 28 & 43.8 & 15 & 71.4 & & 43 & 50.6 \\
\hline
\end{tabular}

Note: Self-reported diseases1: High cholesterol. Diabetes, depression, chest pain, asthma, emphysema, chronic bronchitis, stroke, stomach ulcer or duodenum, gastritis, disc herniation, repetitive stress injury, arthrosis, infarction, Alzheimer's, Parkinson's, kidney disease, cancer, hepatitis, others. Symptoms associated with stress2: Insomnia, stress, nervousness, irritability, dizziness, headache, nausea, vomiting, feeling tired, malaise, intense itching, spotting on the skin, red and irritated eyes. Lack of appetite, joint pain, sneezing, difficulty breathing, mental confusion, muscle pain excessive sweating. Chi-square test. * Fisher's exact test. $\mathrm{N}=85$. ${ }^{* *} \mathrm{~N}=84$

\section{DISCUSSION}

The perception of health is an individual view. WHO defines health status as "a state of complete physical, mental, and social well-being and not just the absence of disease" (20). In this way, social and cultural characteristics may be related to the self-rated response of health status and not only physical health status ${ }^{(21)}$. Previous studies carried out with upper-level educators reported that inactive individuals with lower job satisfaction had higher stress scores ${ }^{(22)}$. Petarli et al. ${ }^{(23)}$ concluded that the factors that negatively influenced the self-rated health status of bank workers were controllable and orientated, and organizational strategies were needed to improve health and work conditions.

In the present study, the variables related to socioeconomic and demographic data did not show an association with the self-rated health status of the educators. These results are similar to those previously reported with bank workers, but in both studies it was possible to observe that women had a higher negative self-rated health status, even if the gender variance was not significant ${ }^{(23)}$. According to the WHO, individuals with a waist circumference higher than the cutoff (man: $>94 \mathrm{~cm}$ and woman: $>80 \mathrm{~cm}$ ) point are at increased risk of developing cardiovascular disease ${ }^{(17)}$. Increased abdominal fat is also associated with metabolic syndrome, systemic arterial hypertension, diabetes mellitus and dyslipidemia, consequently increasing the risk of morbidity and mortality ${ }^{(24,25)}$. Thus, the fact that they have elevated CP and/or inadequate $\mathrm{C} / \mathrm{E}$ ratio may have contributed to negative self-rated health status.

Level of physical activity is associated with self-rated health status ${ }^{(7,23)}$. In this sense Theme Filha et al. ${ }^{(3)}$, presented that physical inactivity is a key factor when associated with other factors such as increased consumption of unhealthy foods and tobacco use, to increasing of Chronic Non-communicable Diseases (CND). On the other hand, physically active individuals may present a lower risk of developing $C N^{(26)}$, since the practice of physical activity is related to a better quality of life, body weight maintenance and being used as one of the prevention methods of obesity ${ }^{(14)}$.

Stress can come from internal sources related to individual and/or external reaction and interpretation related to the demands of daily life due to occupation, family reasons, among others $^{(27)}$. The high level of stress in the workplace caused mainly by psychological and physical demands are responsible for the constant wear and tear of the professionals ${ }^{(28)}$, and the shorter time spent in an administrative position may have contributed to a negative association of the self-rated health status of the educators. Stress responses can be divided into stages of alertness, defense or resistance and exhaustion ${ }^{(27)}$, and it is possible that symptoms may arise as a consequence of a work environment with excessive stress ${ }^{(28)}$. Although the study did not present any significance between educators considered to be stressed and not stressed, the fact that they 
presented 5 or more symptoms related to stress was associated with a negative self-rated health status.

The limitations of this study were the strike period occurred in the year 2016 in the institution, the changes occurred in the schedules and academic calendar post-strike, the number of participating educators and the sample by convenience. The advantages are the pre-scheduling of the collections that allowed us the infrastructure of the rooms used for evaluations, the time granted by each educator and voluntary participation. Despite the limitation in the number of participating educators, it was possible to carry out all the planned steps, contributing to the elaboration of this work.

\section{CONCLUSION}

The time in administrative position and the great number of symptoms related to stress were associated to the negative self-rated health of the educators, due to the accumulation of stress related to the accumulation of work and requirements of the teaching position. Thus, recommending for this group strategies for health promotion and prevention of stress-related diseases. In addition, high waist circumference, inadequate Waist/Stature ratio and low level of physical activity were associated with negative self-rated health, demonstrating that inadequate nutritional status and sedentary lifestyle may have a negative impact on the perception of health. However, these factors can be controlled through clinical nutritional monitoring and physical activity practice, seeking to reduce abdominal fat, through public policies for this group, and can be extended to the other working classes if this is the case.

\section{REFERENCES}

1. Szwarcwald CL, Souza Júnior PRB, Esteves MAP, Damacena GN, Viacava F. Socio-demographic determinants of self-rated health in Brazil. Rio de Janeiro: Cad Saúde Pública. 2005; 21: 54-64.

2. Pavão ALB, Werneck GL, Campos MR. Autoavaliação do estado de saúde e a associação com fatores sociodemográficos, hábitos de vida e morbidade na população: um inquérito nacional. Rio de Janeiro: Cad Saúde Pública. 2013; 29(4):723-734.

3. Theme Filha MM, Souza Junior PRB, Damacena GN, Szwarcwald CL. Prevalência de doenças crônicas não transmissíveis e associação com autoavaliação de saúde: Pesquisa nacional, 2013. Rev. Bras. Epidemiol. [online]. 2015; 18(2): 83-96. Disponível em: http://dx.doi. org/10.1590/1980-5497201500060008. Acesso em: 26 set 2018.

4. Franks P, Gold MR, Fiscella K. Sociodemographics, self-rated health, and mortality in the US. Soc Sci Med. 2003; 56:2505-14.

5. World Health Organization (WHO). Obesity: preventing and managing the global epidemic. World Health Organization, 2000.

6. Carvalho AT, Malta DC, Barros MBA, Oliveira PNFP, Mendonça DMMV, Barros H. Desigualdades na autoavaliação de saúde: uma análise para populações do Brasil e de Portugal. Rio de Janeiro: Cad Saúde Pública. 2015; 31(11): 2449-2461.
7. Manderbacka K, Lundberg O, Martikainen P. Do risk factors and health behaviours contribute to self-ratings of health? 48. ed. São Paulo: Elsevier; 1999.

8. Theme Filha MMT, Costa MAS, Guilam MCR. Occupational stress and selfrated health among nurses. Rev. Latino-Am Enfermagem. [online]. 2013; 21(2), 475- 483. Disponível em: https://dx.doi.org/10.1590/s010411692013000200002. Acesso em: 20 set 2018.

9. Milner A, Witt K, Spittal MJ, Bismark M, Graham M, La Montagne AD. The relationship between working conditions and self-rated health among medical doctors: evidence from seven waves of the Medicine In Australia Balancing Employment and Life (Mabel) survey. BMC Health Services Research. [online]. 2017; 17(1), 1-10. Disponível em: https:// dx.doi.org/10.1186/s12913-017-2554- z . Acesso em 20 set 2018

10. Marques JR. No stress: saiba quais são as profissões mais estressantes. Portal IBC. (Goiânia-GO) [online]. 2018. Disponível em: https://www. ibccoaching.com.br/portal/no-stress-saiba-quais-sao-as-profissoes-maisestressantes/. Acesso em 27 de set 2018.

11. Borsoi ICF. Trabalho e produtivismo: saúde e modo de vida de docentes de instituições públicas de Ensino Superior. Cad Psicol Soc Trab. 2012; 15 : 81-100.

12. Associação Brasileira das Empresas de Pesquisa (ABEP). Critério Padrão de Classificação Econômica Brasil. São Paulo: ABEP; 2013; 1-3.

13. Blackburn GL, Thornton PA. Nutritional assessment of the hospitalized patients. Medi Clin North Am [S.I]. 1979;63(5):1103-115.

14. Associação Brasileira para o Estudo da Obesidade e da Síndrome Metabólica (ABESO). Diretrizes brasileiras de obesidade 2016 / ABESO - Associação Brasileira para o Estudo da Obesidade e da Síndrome Metabólica. 4.ed, 2016.

15. Malachias MVB, Souza WKSB, Plavnik FL, Rodrigues CIS, Brandão AA, Neves MFT, et al. IV Diretriz Brasileira de Hipertensão Arterial. Sociedade Brasileira de Cardiologia. Arquivos Brasileiros de Cardiologia 2016; 107(3)7-12.

16. Matsudo S, Araújo T, Marsudo V, Andrade D, Andrade E, Oliveira LC, et al. Questionário Internacional de Atividade Física (IPAQ): Estudo de Validade e Reprodutibilidade no Brasil. São Paulo: Rev. Bras. Ativ. Fís. Saúde. 2012; $6(2): 5-18$.

17. World Health Organization (WHO). Global recommendations on physical activity for health, Geneva: World Health Organization; 2011.

18. Alves VV, Borges KCS, Ribeiro LFP, Gadelha SR, Santos SC. Concordância entre critérios de categorização do nível de atividade física a partir do questionário internacional de atividade física. Ilhéus: Rev. Bras. Ativ. Fís. Saúde. 2012;15(2):111-114.

19. Karasek R, Theorell T. Healthy work: Stress, productivity and the reconstruction of working life. New York, NY: Basic Books. 1992.

20. World Health Organization (WHO). Preamble to the constitution of th World Health Organization as adopted by the International Health Conference. Report of a WHO Expert Committee. New York.1948.

21. Prass PBB, Oliveira WS. A interface da autoavaliação em saúde dos professores e seu preparo para abordagem do tema na escola. Ver. Bras. Cienc. Saúde. 2015; 1(1):45-52.

22. Camargo EM, Oliveira MP, Rodriguez-Añez CR, Hino AAF, Reis RS. Estresse percebido, comportamentos relacionados à saúde e condições de trabalho de professores universitários. Psicol. Argum. 2013; 31(75):589-597.

23. Petarli GB, Salaroli LB, Bissoli NS, Zandonade E. Autoavaliação do estado de saúde e fatores associados: um estudo em trabalhadores bancários. Rio de Janeiro: Cad Saúde Pública. 2015;31(4):787-799. 
24. World Health Organization (WHO). Waist circumference and waist-hip ratio: Report of a WHO expert consultation, Geneva. 2008.

25. Barroso TA, Marins LB, Alves R, Gonçalves ACS, Barroso SG, Rocha GS. Associação Entre a Obesidade Central e a Incidência de Doenças e Fatores de Risco Cardiovascular. Niterói: Int J Cardiovascul Sci. 2017; 30(5):416424.

26. Lima GO, Machado BM, Klein SK, Formentin CM, Garlipp DC. Nível de atividade física e risco de desenvolvimento de doenças cardiovasculares em acadêmicos dos cursos de educação física. São Paulo: RBPFEX. 2017; 11(68):542-549.

27. Koch MO, BIAZI RJ, Benedetto CD. Estresse em docentes: um estudo comparativo entre uma Instituição de Ensino Superior Pública e uma Instituição de Ensino Superior Privada na Cidade de Toledo-Pr. Paraná: Rev. Uningá Review. 2015; 21(1):17-23.

28. Santos JAA, Calles ACN. A avaliação do nível de estresse e a consequência sobre a variabilidade da frequência cardíaca em docentes. Semin. Ciênc. Biol. Saúde. 2016; 3(3):215-226.

\section{AUTHOR'S CONTRIBUTION}

Each author contributed individually and significantly to the design of this manuscript. RLR, JMQM and DSB were the main contributors to the intellectual conception of the study; RLR, JHG, WAB and CMS participated in data collection and analysis and writing development; RLR, FLPJ and GAJ are involved in reviewing the results and writing the manuscript; RLR, AFM and DSB participated in the critical review of the manuscript.

\section{CONFLICT OF INTEREST}

The author(s) declare that they have no competing interests.

\section{AUTHORS DETAILS}

1 Departamento de Educação Integrada em Saúde (DEIS) da Universidade Federal do Espírito Santo (UFES), Vitória (ES), Brasil

${ }^{3}$ Departamento de Pós-Graduação em Educação Física da Universidade São Judas Tadeu (USJT), São Paulo (SP), Brasil

${ }^{4}$ Departamento de Fisiologia - Universidade Federal de São Paulo (UNIFESP), São Paulo (SP), Brasil 